\title{
Ensuring Requirements for Emissions of Harmful Substances of Diesel Engines
}

\author{
G. M. Kuharonak ${ }^{1)}$, D. V. Kapskiy ${ }^{1)}$, V. I. Berezun ${ }^{2)}$ \\ ${ }^{1)}$ Belarusian National Technical University (Minsk, Republic of Belarus), \\ ${ }^{2)}$ JSC AMKODOR, Holding Managing Company (Minsk, Republic of Belarus) \\ (C) Белорусский национальный технический университет, 2020 \\ Belarusian National Technical University, 2020
}

\begin{abstract}
The purpose of this work is to consider the requirements for emissions of harmful substances of diesel engines by selecting design and adjustment parameters that determine the organization of the workflow, and the exhaust gas cleaning system, taking into account the reduction of fuel consumption. Design elements and geometric characteristics of structures for a turbocharged diesel engine of Д-245 series produced by JSC HMC Minsk Motor Plant (4ЧН11/12.5) with a capacity of $90 \mathrm{~kW}$ equipped with an electronically controlled battery fuel injection have been developed: exhaust gas recirculation along the high pressure circuit, shape and dimensions of the combustion chamber, the number and angular arrangement of the nozzle openings in a nozzle atomizer, and inlet channels of the cylinder head. Methods for organizing a workflow are proposed that take into account the shape of the indicator diagrams and affect the emissions of nitrogen oxides and dispersed particles differently. Their implementation allows us to determine the boundary ranges of changes in the control parameters of the fuel supply and exhaust gas recirculation systems when determining the area of minimizing the specific effective fuel consumption and the range of studies for the environmental performance of a diesel engine. The paper presents results of the study on the ways to meet the requirements for emissions of harmful substances, obtained by considering options for the organization of working processes, taking into account the reduction in specific effective fuel consumption, changes in the average temperature of the exhaust gases and diesel equipment. To evaluate these methods, the following indicators have been identified: changes in specific fuel consumption and average temperature of the toxicity cycle relative to the base cycle, the necessary degree of conversion of the purification system for dispersed particles and $\mathrm{NO}_{x}$. Recommendations are given on choosing a diesel engine to meet Stage 4 emission standards for nitrogen oxides and dispersed particles.
\end{abstract}

Keywords: requirements, emissions, harmful substances, installation, model, research, design parameters, ecology, toxicity cycle, process, fuel efficiency

For citation: Kuharonak G. M., Kapsky D. V., Berezun V. I. (2020) Ensuring Requirements for Emissions of Harmful Substances of Diesel Engines. Science and Technique. 19 (4), 305-310. https://doi.org/10.21122/2227-1031-2020-19-4-305-310

\section{Обеспечение требований к выбросам вредных веществ дизелей}

\author{
Докт. техн. наук, проф. Г. М. Кухарёнок'), докт. техн. наук Д. В. Капский1), \\ канд. техн. наук В. И. Березун ${ }^{2}$ \\ ${ }^{1)}$ Белорусский национальный технический университет (Минск, Республика Беларусь), \\ ${ }^{2)} \mathrm{OAO}$ «АМКОДОР» - управляющая компания холдинга» (Минск, Республика Беларусь)
}

Реферат. Рассмотрены требования к выбросам вредных веществ дизелей путем выбора конструктивных и регулировочных параметров, определяющих организацию рабочего процесса, и системы очистки отработавших газов с учетом снижения расхода топлива. Разработаны элементы и геометрические характеристики конструкций для дизеля с турбонаддувом серии Д-245 производства ОАО «УКХ «Минский моторный завод» (4ЧН11/12,5) мощностью 90 кВт, оснащенного аккумуляторной системой впрыска топлива с электронным управлением (система рециркуляции отработавших газов по контуру высокого давления, форма и размеры камеры сгорания, количество и угловое расположение сопловых отверстий распылителя форсунки и впускные каналы головки блока цилиндров). Предложены способы организации рабочего процесса, учитывающие форму индикаторной диаграммы, по-разному влияющие на выбросы оксидов азота и дисперсных частиц. Их реализация позволяет определить граничные диапазоны изменения регулировочных параметров систем топливоподачи и рециркуляции отработавших газов при определении области минимизации удельного эффективного расхода топлива и диапазона изучения экологических показателей дизеля. Приведены результаты исследования способов обеспечения требований к выбросам вредных веществ, полученные путем рассмотрения вариантов организации рабочих процессов с учетом снижения удельного эффективного расхода

\section{Адрес для переписки}

Кухарёнок Георгий Михайлович

Белорусский национальный технический университет

ул. Я. Коласа, 12,

220013, г. Минск, Республика Беларусь

Тел.: +375 17 292-81-86

dvs_atf@bntu.by

\author{
Address for correspondence \\ Kuharonak Georgy M. \\ Belarusian National Technical University \\ 12, Ya. Kolasa str., \\ 220013, Minsk, Republic of Belarus \\ Tel.: +375 17 292-81-86 \\ dvs_atf@bntu.by
}


топлива, изменения средней температуры отработавших газов и комплектации дизеля. Для оценки этих способов выделены показатели: изменение удельного расхода топлива и средней температуры цикла токсичности по отношению к базовому циклу, необходимая степень конверсии системы очистки по дисперсным частицам и $\mathrm{NO}_{x}$. Даны рекомендации по выбору комплектации дизеля для обеспечения норм Stage 4 по выбросам оксидов азота и дисперсных частиц.

Ключевые слова: требования, выбросы, вредные вещества, установка, модель, исследования, конструктивные параметры, экология, цикл токсичности, процесс, топливная экономичность

Для цитирования: Кухарёнок, Г. М. Обеспечение требований к выбросам вредных веществ дизелей / Г. М. Кухарёнок, Д. В. Капский, В. И. Березун // Наука и техника. 2020. Т. 19, № 4. С. 305-310. https://doi.org/10.21122/2227-10312020-19-4-305-310

\section{Introduction}

Constant tightening of the requirements for diesel engines, directed the vector of development of the world engine-building towards improving environmental performance [1-8]. For a diesel engine, the greatest difficulty is the reduction of emissions of nitrogen oxides $\left(\mathrm{NO}_{x}\right)$ and particulate matter (PM), the maximum level of which is determined by the requirements of the technical regulations of the Customs Union. The reduction of emissions of harmful substances (BBB) is due to the finding of a compromise between the degree of complication of the diesel engine design and the efficiency of exhaust gas cleaning (OG) [1-3].

The decisive influence on emissions of harmful substances and fuel-economic indicators of a diesel engine is provided by the adjustment parameters: fuel injection pressure $P_{i n}$, injection advance angle $\theta$ and exhaust gas recirculation rate $\rho$ [9-11]. However, the range shift of the effective values of the variable parameters is determined by the basic design parameters of the engine. The use of battery injection systems allows flexible control of the injection pressure and the injection advance angle without complicating the design, and together with the HORG system, they allow the design parameters of the engine to be coordinated for different operating modes.

The purpose of this work is to ensure the requirements for emissions of harmful substances of diesel engines by selecting design and adjustment parameters that determine the organization of the workflow, and the exhaust gas cleaning system, taking into account the reduction of fuel consumption.

\section{Main part}

A test facility for complex research of diesels workflows and $\mathrm{NO}_{x}$ and $\mathrm{PM}$ emission estimation has been worked out (Fig. 1). Its peculiar features are the following: automation of measurement and data smoothing processes, on-line monitoring of the eye diagram changes, the beginning of injection and injection duration, recycle rate control of $\mathrm{CO}_{2}$ concentration in engine exhaust of the inlet gas [12-16].

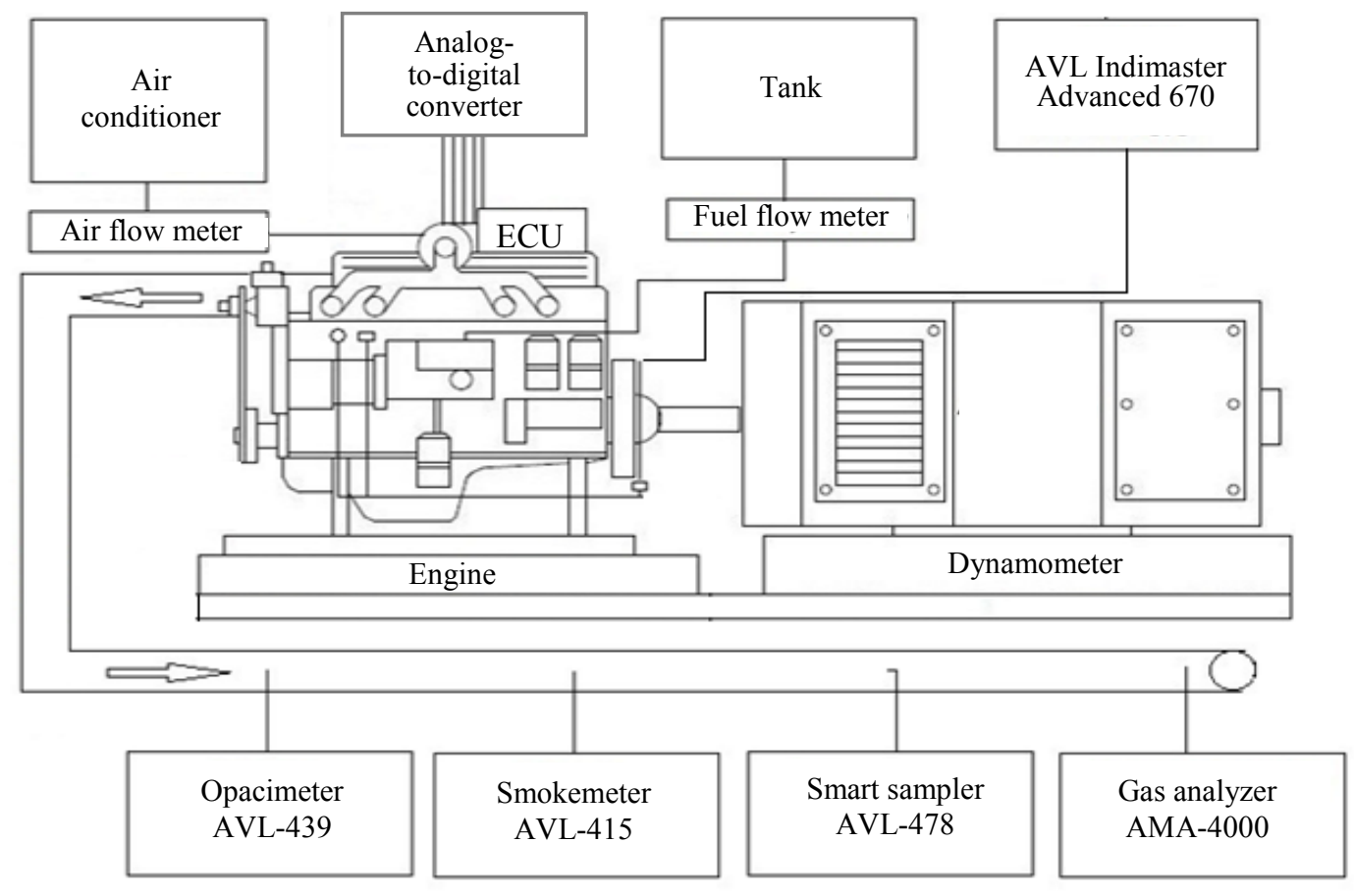

Fig. 1. Test facility lay-out 
The test facility meets all the international UNO requirements (Rules No 24, 49, 96).

An investigating methodology has been developed. According to it, for the efficient use of time and labor cost reduction the sequence of parameter changes $P_{i n}, \theta$ and $\rho$ in providing an operating mode speed and torque $=$ const was defined by the saturated plan of the experiment, which allows to express the acquired results in terms of quadratic regression equations. The required engine power was compensated for changing the quantity of the injection rate. For engine trend monitoring in order to reject misleading tests data while carrying out experimental research the verification of fuel-economic and ecological figures was provided on the chosen in advance control point with the equal fuel-injection equipment alignments and the degree of EGR.

The reproducibility of measurements was provided by systematic equipment calibration and check-out. Studies were conducted on the choice of design parameters with regard to improving environmental performance and reduce specific fuel consumption $g_{e}$. The following were configuration parameters study has been carried out with account for ecological performance improvement and corrected car economy $\left(g_{e}\right)$ on the basis of a produced by Minsk Motor Plant $90 \mathrm{kWt}$ turbocharged diesel (D-245 production number) which is equipped with the electronic fuel injection system. The following characteristics have been investigated: the shape of the combustion chamber, angular placement of the spray sparger, its configuration and the quantity of its nozzle holes, swirl ratio of inlet ports of the engine cylinder head, gas distribution phases and the way of exhaust gas recirculation organization [17-24]. As a result, regulated EGR contoured by high pressure with the chill of circulated exhaust gas has been chosen. The developed elements of the configuration are in Fig. 2.

It has been revealed that the adjustment parameters $P, \theta$ and $\rho$ which are changing in the engine's working process, play a crucial role in the working process organization that provides upholding ecological safety standards.

To carry out computational studies, a combined mathematical model of the diesel engine working process with the EGR system has been developed, based on the first law of thermodynamics, including the method of calculating the combustion process N. F. Razleitseva with refined coefficients, and the resulting empirical dependencies for calculating emissions of dispersed particles and exhaust gas temperature after the turbocharger [25-28]. To check the adequacy of the mathematical model, the calculation results for the nominal mode were compared with experimental data.

The compliance of the calculated form of the indicator diagram (ID) according to Fisher's criterion [5], which is the quotient of dividing the estimate of the variance of the $S_{D}$ inadequacy by the estimate of the error of the single observation $S_{e}$, was performed

$$
F=\frac{S_{D} / \varphi_{n}}{S_{e} / \varphi_{d}}
$$

where $\varphi_{n}-$ number of degrees of freedom of numerator; $\varphi_{d}$ - number of degrees of freedom of denominator.

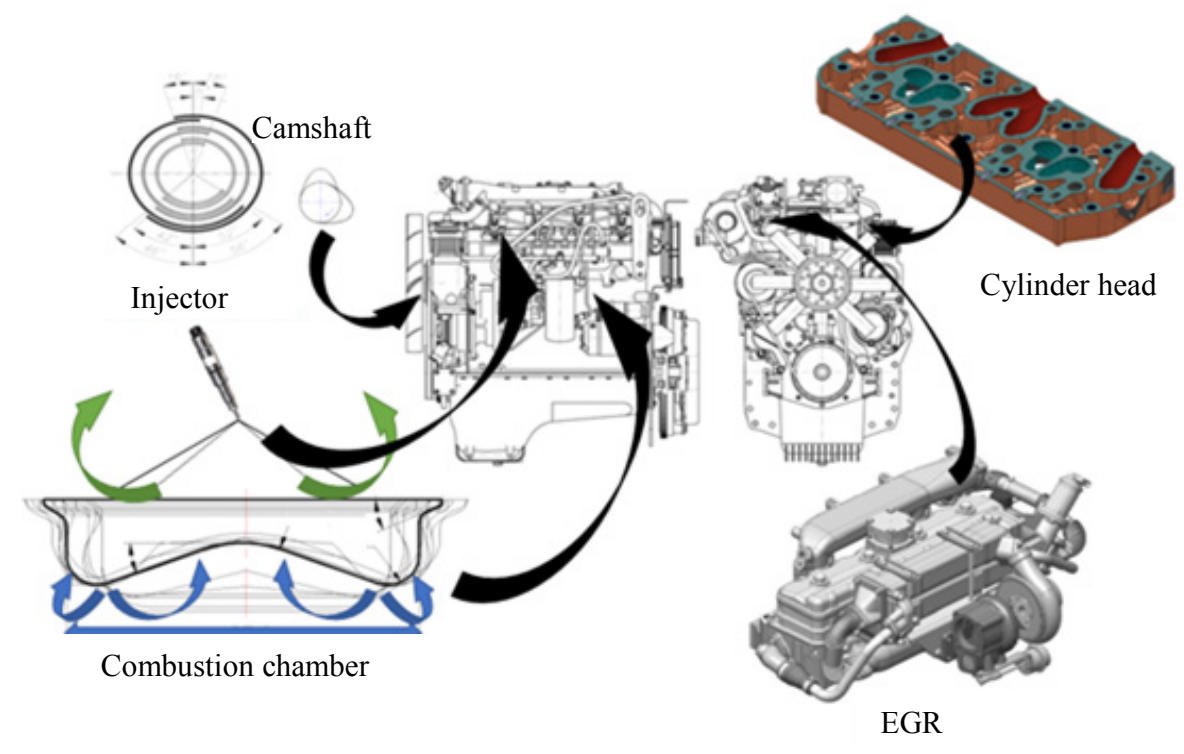

Fig. 2. Developed elements of the study object configuration 
The observed value $F=1.08<F_{c r}=1.16$ for statement performance probability $P_{b}=0.95$ provides support for the model adequacy.

Dispersion numbers of the effective marker in examining the calculation sufficiency $\mathrm{NO}_{x}, \mathrm{PM}$ and $T_{r}^{\prime}$ do not drop lower than $94 \%$. It testifies to the high statistical significance of characteristic curve for its calculation.

As a result, three means of the workflow organization have been singled out which influence $\mathrm{NO}_{x}$ and RM emission in different ways [29]. These means are determined by the type of ID that are shown in Fig. 3.

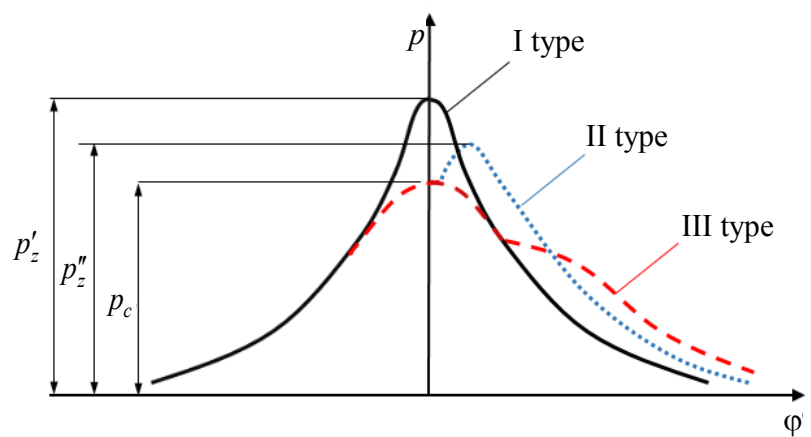

Fig. 3. Indicator diagrams

The first type (I type) is a one-humped ID depicting the ratio of peak combustion pressure to compressive pressure $p_{z} / p_{c}>1$; II type is a doublehumped ID depicting $p_{z} / p_{c}>1$ and III type is a double-humped ID depicting $p_{z} / p_{c} \leq 1$ (with an indistinct peak $p_{z}$ ).

Calculated analyses of $\mathrm{PM}$ and $\mathrm{NO}_{x}$ emission adjustment parameters according to the saturated plan of the experiment for each NRSC ecological cycle mode have been conducted [12]. The margin limits of the variation range have been chosen according to the working processes in the area of the ID (three types). The variation range of $P$ and $\rho$ has been limited by the fuel consumption rate of the initial related type stage along with the correlated ecological parameters. As an additional restricting parameter the exhaust gas temperature after the turbocharger $T_{r}^{\prime}$ ' has been taken, which has been restricted with account of the study subject technical specifications. The margin limits of the adjustment parameters allow to define the minimization area $g_{e}$ as well.

In order to choose the fuel supply parameters and the exhaust fume recycle rate the simulation data has been analyzed as well as the obtained regressional dependence with regard of the ID type. Taking into consideration generally accepted emission reduction strategies for each peak of NRSC cycle target-oriented approaches to solving the problems have been searched for. For the peak of the ecological cycle H-100 substantiation of combustion process parameters data is in Fig. 4. The data analysis has been performed in the following three directions:

1) minimization $g_{e}\left(g_{\text {emin }}\right)$;

2) $\mathrm{PM}$ minimization $\left(\mathrm{PM}_{\min }\right)$;

3) $\mathrm{NO}_{x}$ minimization $\left(\mathrm{NO}_{x \min }\right)$.

For the first direction the following parameters have been chosen: $P_{\text {in }}=160 \mathrm{MPa}, \theta=10$ degrees and $\rho=0.12$ if emitted $\mathrm{NO}_{x}=6.07 \mathrm{~g} /(\mathrm{kW} \cdot \mathrm{h})$, $\mathrm{PM}=0.04 \mathrm{~g} /(\mathrm{kW} \cdot \mathrm{h})$ and $g_{e}=214.2 \mathrm{~g} /(\mathrm{kW} \cdot \mathrm{h})$.

While calculating the whole body of data the results of the search for $\mathrm{NO}_{x}$ and $\mathrm{PM}$ minimization determine nonrational parameters from the point of view of fuel-economic figures. It shows itself in the choice of extreme settings of the working process in the range under consideration.

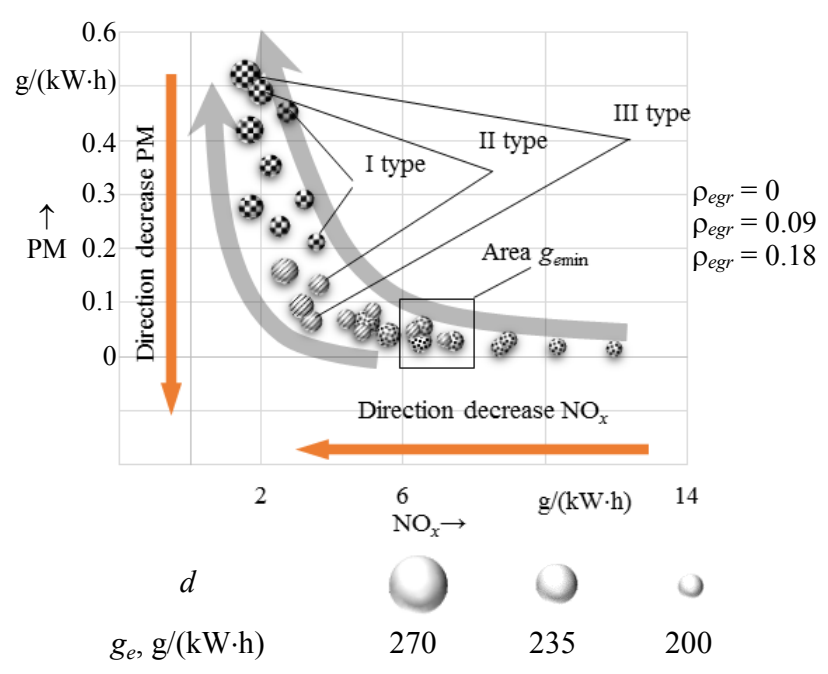

Fig. 4. $\mathrm{PM}-\mathrm{NO}_{x}$ diagram for nominal conditions

Consequently, for the $2^{\text {nd }}$ and $3^{\text {rd }}$ directions the solutions have been searched for in limiting fuel consumption in relation to the data of the $1^{\text {st }}$ direction $\left(g_{e m i n}\right)$. To minimize PM the search for solutions was made in the following two ways: $\mathrm{NO}_{x}$ increasing and $\mathrm{NO}_{x}$ decreasing by means of imposing an additional boundary condition. The simulated result of the three directions of the emission reduction strategy for the cycle H-100 is depicted in the paper. As percentage in Fig. 5 fuel consumption variation is expressed.

In the proposed variant of decision making organization the parameters of fuel consumption degradation tend to organize the working process with 
the initial stage of the indicator diagram and a transition from type I to type III. This is reflected in the fact of $\theta$ decrease while $P_{\text {in }}$ is maintained at the upper variation limit. The difference in $\mathrm{NO}_{x}$ and PM minimization consists only in the fact that in the former case $\rho$ is in the value range of 0.16 , but in the latter case it approximates 0 .

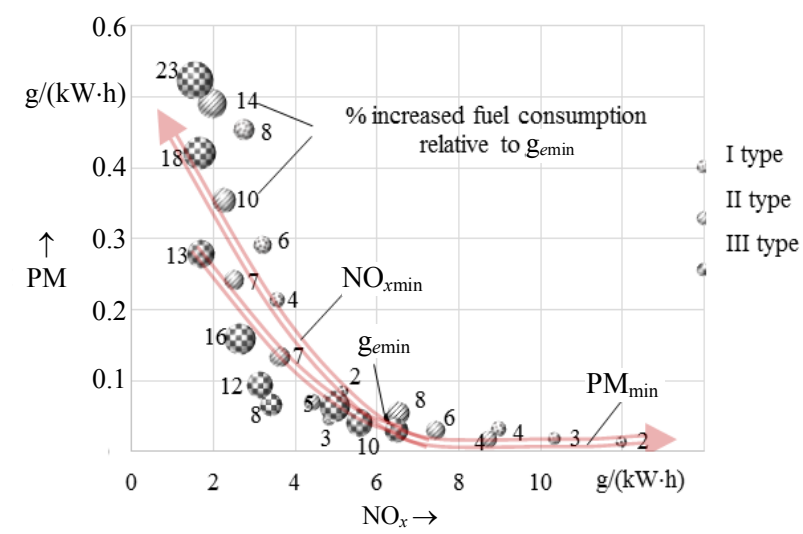

Fig. 5. Dimensions of ecological indices improvement for nominal operation conditions

In the areas of the obtained values, a study was conducted on ways to reduce diesel emissions, for the evaluation of which the following indicators were highlighted:

$\Delta g_{e}$ - is the change in fuel consumption in relation to the base cycle;

$\Delta T_{c r}$ - is the change in the average temperature of the toxicity cycle relative to the base cycle;

$C_{\mathrm{PM}}, C_{\mathrm{NO} x}-$ is the required degree of conversion of the purification system for $\mathrm{PM}$ and $\mathrm{NO}_{x}$ to achieve the standards of Stage 4, defined as the ratio of the difference between the values of "raw" and normalized emissions to the value of "raw" emissions.

Five stages of workflows calculation have been identified with account for fuel consumption with load increase, toxicity level factor weight and the presence of the EGR system (Tab. 1).

Table 1

$\mathrm{NO}_{x}$ and PM emission reduction strategies data

\begin{tabular}{|c|c|c|c|c|c|c|c|}
\hline $\begin{array}{c}\text { Calculation } \\
\text { stage }\end{array}$ & $\begin{array}{c}\mathrm{NO}_{x}, \\
\mathrm{~g} /(\mathrm{kW} \cdot \mathrm{h})\end{array}$ & $\begin{array}{c}\mathrm{PM} /(\mathrm{kW} \cdot \mathrm{h}) \\
\mathrm{g})\end{array}$ & $\begin{array}{c}\Delta g_{e}, \\
\%\end{array}$ & $\begin{array}{c}\Delta T_{\text {avr }}, \\
\mathrm{K}\end{array}$ & $C_{\mathrm{PM}}$ & $C_{\mathrm{NO} x}$ & $\mathrm{EGR}$ \\
\hline 1 & 8.1 & 0.031 & - & - & 0.20 & 0.95 & + \\
\hline 2 & 5.1 & 0.089 & 10.9 & 54 & 0.70 & 0.92 & + \\
\hline $\mathbf{3}$ & $\mathbf{1 3 . 1}$ & $\mathbf{0 . 0 1 4}$ & $\mathbf{2 . 4}$ & $\mathbf{4}$ & - & $\mathbf{0 . 9 7}$ & - \\
\hline $\mathbf{4}$ & $\mathbf{7 . 7}$ & $\mathbf{0 . 0 2 5}$ & $\mathbf{2 . 4}$ & $\mathbf{4}$ & - & $\mathbf{0 . 9 5}$ & + \\
\hline 5 & 2.5 & 0.265 & 12.0 & 81 & 0.91 & 0.83 & + \\
\hline
\end{tabular}

At the first stage to compose the basic toxicity level for each mode the workflow settings have been chosen which provide $g_{e}$ minimization. The summary $\mathrm{NO}_{x}$ and $\mathrm{PM}$ emission indicators have been $8.100 \mathrm{~g} /(\mathrm{kW} \cdot \mathrm{h})$ and $0.031 \mathrm{~g} /(\mathrm{kW} \cdot \mathrm{h})$ respectively. At the same time the exhaust gas temperature according to the toxicity level constitutes $647 \mathrm{~K}$.

At the $2^{\text {nd }}$ and $3^{\text {rd }}$ stages a PM reduction strategy has been fulfilled involving the use of EGR system and its excluding. As a result, for the engine configuration without the EGR system the cycle with $\mathrm{NO}_{x}$ and $\mathrm{PM}$ of $13.1 \mathrm{~g} /(\mathrm{kW} \cdot \mathrm{h})$ and $0.014 \mathrm{~g} /(\mathrm{kW} \cdot \mathrm{h})$ has been obtained respectively. It allows to meet PM Stage 4 regulations without the use of the EGR system. Herewith, $\Delta g_{e}$ is $2.4 \%$, but the $\Delta T_{a v r}$ increase is $4 \mathrm{~K}$. For the engine configuration without the EGR system $\mathrm{NO}_{x}$ and PM emission constitutes $5.100 \mathrm{~g} /(\mathrm{kW} \cdot \mathrm{h})$ and $0.089 \mathrm{~g} /(\mathrm{kW} \cdot \mathrm{h})$ respectively, $\Delta g_{e}$ is $10.9 \%$ and the $\Delta T_{a v r}$ increase is $54 \mathrm{~K}$.

At the $4^{\text {th }}$ calculation stage the strategy of meeting PM reduction within the framework of Stage 4 regulations was considered with the opportunity to reduce $\mathrm{NO}_{x}$ by using the EGR system. The PM value of $0.025 \mathrm{~g} /(\mathrm{kW} \cdot \mathrm{h})$ within a cycle has been successful with the $\mathrm{NO}_{x}$ emission of $7.7 \mathrm{~g} /(\mathrm{kW} \cdot \mathrm{h})$ and with the $\Delta T_{a v r}$ increase of $4 \mathrm{~K}$ together with the $\Delta g_{e}$ increase of $2.4 \%$.

At the $5^{\text {th }}$ calculation stage a $\mathrm{NO}_{x}$ reduction strategy has been fulfilled. The cycle obtained provided $\mathrm{NO}_{x}$ and $\mathrm{PM}$ with $2.500 \mathrm{~g} /(\mathrm{kW} \cdot \mathrm{h})$ and $0.265 \mathrm{~g} /(\mathrm{kW} \cdot \mathrm{h})$ respectively, $\Delta g_{e}$ has increased by $12 \%$ and $\Delta T_{a v r}$ - by $81 \mathrm{~K}$.

The choice of the emission reduction strategies was made with regard of fuel consumption and the reduction of engine configuration elements. Especially appealing are the strategies within the framework of PM Stage 4 regulations (variants 3 and 4).

\section{CONCLUSIONS}

1. The design parameters of the combustion chamber, cylinder head, nozzle and exhaust gas recirculation system of diesel engine are defined, allowing to organize the flow of the working process, taking into account the improvement of environmental and fuel-economic indicators.

2. Methods of workflow organization are proposed that differ in the shape of the indicator diagram, allowing to determine the range of changes in the parameters of fuel supply control and exhaust gas recirculation during each toxicity cycle mode. 
3. Methods to meet the requirements for emissions of harmful substances from a diesel engine, differing in the priority of fuel efficiency with increasing load, the weighting factors of the toxic cycle, the exhaust gas temperature after the turbocharger and the degree of conversion of the exhaust gas cleaning system are investigated.

\section{REFERENCES}

1. Markov V. A., Bashirov R. M., Gabitov I. I. (2002) Diesel Exhaust Toxicity. Moscow, Publishing House of Bauman Moscow State Technical University. 376 (in Russian).

2. Grekhov L. V., Ivaschenko N. A., Markov V. A. (2004) Fuel Equipment and Diesel Control Systems. Moscow, Legion-Avtodata Publ. 344 (in Russian).

3. Basshuysen R., Schäfer F. (2015) Handbuch Verbrennungsmotor. Grundlagen, Komponenten, Systeme, Perspektiven. Wiesbaden, Vieweg \& Sohn Verlag. 1032. https://doi.org/10.1007/978-3-658-04678-1.

4. Zvonov V. A., Zaigraev L. S., Chernykh V. I., Kozlov A. V. (2004) Ecology of Automotive Internal Combustion Engines. Lugansk, Volodymyr Dahl East Ukrainian National University. 268 (in Russian).

5. Parsadanov I. V. (2003) Improvement of Quality and Competitiveness of Diesel Engines Based on the Fuel and Environmental Criterion. Kharkov, Publishing Centre of National Technical University "Kharkiv Polytechnic Institute". 244 (in Russian).

6. Kulchitskii A. R. (2000) Toxicity of Automotive and Tractor Engines. Vladimir, Publishing House of Vladimir State University. 256 (in Russian).

7. Eurasian Economic Commission (2012) TR TS 031/2012. On the Safety of Agricultural and Forestry Tractors and their Trailers. Minsk, Ekonomenergo Publ. 60 (in Russian).

8. Heck R., Farrauto R., Galati S. (2009) Catalytic Air Pollution Control. NY, JohnWiley\&Sons. 391. https://doi.org/10. 1002/9781118397749.

9. Kukharonak H. M., Berezun V. I. (2013) Diesel Emission Reduction. Improvement of Traffic and Transport Organization for Passengers and Goods. Minsk, Belarusian National Technical University, 314-323 (in Russian).

10. Berezun V. I. (2013) High-Performance Energy-Efficient Engines for Off-Road Vehicles. Problemy i Perspektivy Razvitiya Transportnykh Sistem $i$ Stroitel'nogo Kompleksa: Materialy III Mezhdunarodnoi Nauchno-Prakticheskoi Konferentsii: [Problems and Prospects for Development of Transport Systems and Building Complex: Materials of the III International Scientific and Practical Conference]. Gomel, Belarusian State University of Transportation, 157-158 (in Russian).

11. Dieselmotor-Management. $3^{\text {rd }}$ ed. [Diesel Engine Control Systems]. Robert Bosch GmbH, 2002. 480 (in German).

12. Kukharonak H. M., Berezun V. I. (2018) Influence of Fuel Supply and Exhaust Gas Recirculation on Emissions of Harmful Substances from Diesel Engines. Avtomobil'nyi Transport [Automobile Transport], (42), 5-11 (in Russian).

13. Kukharonak H. M., Marchuk A. N. (2010) Experimental Setup for Studying Starting Qualities of Diesel Engines with Electronic Fuel Supply Control. Visnik Skhidnoukrä̈ns'kogo Natsional'nogo Universitetu imeni Volodimira Dalya $=$ Visnik of the Volodymyr Dahl East Ukrainian National University, (6), 80-84 (in Russian).

14. Concerto Software Version 3.7. Graz: AVL List, 2004. 916.

15. Smoke Value Measurement with the Filter-Paper-Method. Graz: AVL List, 2004. 112.
16. Product Guide AVL SMART SAMPLER 478. Graz: AVL List, 2004. 176. A. N.

17. Kukharonak H. M., Petruchenko A. N., Berezun V. I. (2014) Diesel Engine Emissions Reduction. Moscow, Novoe Znanie Publ. 220 (in Russian).

18. Kukharonak H. M., Sevizdral S. P., Berezun V. I. (2012) Provision of Environmental Indicators of Euro-4 and Euro-5 Level for Automobile Diesels of the Minsk Motor Plant. Vesti Avtomobil'no-Dorozhnogo Instituta $=$ Bulletin of Automobile and Highway Institute, 14 (1), 95-105 (in Russian).

19. Sevizdral S. P., Berezun V. I. (2013) State of the Issue and Prospects for the Development of Engine-Building in the Republic of Belarus. Zhurnal Assotsiatsii Avtomobilnykh Inzhenerov [Journal of Association of Automotive Engineers], 83 (6), 6-7 (in Russian).

20. Kukharonak H. M., Berezun V. I. (2014) Selection of Parameters for System of Diesel Engine Exhaust Gas Recirculation. Nauka i Tekhnika = Science \& Technique, (1), 57-63 (in Russian).

21. Kukharonak H. M., Petruchenko A. N., Berezun V. I. (2014) Choice of Diesel Engine Combustion Chamber shape. Vestnik SevGTU. Mashinopriborostroenie i Transport [Bulletin of Sevastopol National Technical University. Engineering and Transport], (152), 65-68 (in Russian).

22. Kukharonak H. M., Berezun V. I. (2014) Choice of Shape for Combustion Chamber of Diesel Engine with Low Injection Intensity. Sovershenstvovanie Organizatsii Dorozhnogo Dvizheniya i Perevozok Passazhirov i Gruzov. Sbornik Nauchnykh Trudov: po Rezul'tatam Ezhegodnoi Mezhdunarodnoi Nauchno-Prakticheskoi Konferentsii [Improvement in Organization of Traffic and Transport of Passengers and Goods. Collection of Scientific Papers: According to the Results of the Annual International Scientific-Practical Conference]. Minsk, Belarusian National Technical University, 180-184 (in Russian).

23. Berezun V. I. (2014) Study of Methods for Organizing Exhaust Gas Recirculation. Nauka - Obrazovaniiu, Proizvodstvu, Ekonomike. Materialy 12 Mezhdunarodnoi Nauch.Tekhn. Konf. T. 2 [Science to Education, Industry, Economics. Proceedings of $12^{\text {th }}$ International Science and Technical Conference. Vol. 2]. Minsk, BNTU, 56-57 (in Russian).

24. Berezun V. I. (2013) Performance Indicators for High Power Density Engines. Sovershenstvovanie Organizatsii Dorozhnogo Dvizheniya i Perevozok Passazhirov i Gruzov. Sbornik Nauchnykh Trudov [Improvement in Organization of Traffic and Transport of Passengers and Goods. Collection of Scientific Papers]. Minsk, BNTU, 333-337 (in Russian).

25. Razleytsev N. F. (1980) Modeling and Optimization of the Combustion Process in Diesel Engines. Kharkov, Vishcha Shkola Publ. 169 (in Russian).

26. Hiroyasu H., Kadota T., Arai M. (1983) Development and Use of a Spray Combustion Modeling to Predict Diesel Engine Efficiency and Pollutant Emissions. Part 1. Combustion Modeling. Bulletin of the JSME, 26 (214), 569-575. https://doi.org/10.1299/jsme1958.26.569.

27. Kukharonak H. M. (1999) High Speed Diesel Workflow. Methods and Means of Improvement. Minsk, Belarusian State Polytechnical Academy. 180 (in Russian).

28. Kukharonak H. M., Hershan D. G. (2011) Modeling of Characteristics for Fuel Jets and Parameters for Diesel Combustion Chamber. Vestnik BNTU [Bulletin of Belarusian National Technical University], (4), 35-39 (in Russian).

29. Kukharonak H. M. (2018) Improvement of Diesel Engine Workflow. Izobretatel [Inventor], 217 (1), 37-40 (in Russian).

Received: 09.07.2019

Accepted: 15.10.2019

Published online: 30.07 .2020 